\title{
Production and Characterization of Serratiopeptidase Enzyme from Serratia Marcescens
}

\author{
A. Mohankumar (Corresponding author) \\ Department of Zoology, Chikkanna Govt. Arts College, Tirupur 641 602, Tamilnadu, India \\ E-mail: moniver@satyam.net.in \\ R.Hari Krishna Raj \\ Department of Microbiology, Sengunthar Arts and Science College \\ Tiruchengode-637205, Namakkal Dt, India
}

Received: November 5, 2009 Accepted: November 24, 2009 doi:10.5539/ijb.v3n3p39

\begin{abstract}
Production characterization of serratiopeptidase (STP) enzyme by Serratia marcescens was the aim of this study. Serratia marcescens was allowed to grow in Tryptone Yeast Extract Glucose broth culture for the purpose of inducing STP (serrapeptase or serratiopeptidase) enzyme. The optimal conditions for STP production by Serratia marcescens were; $0.5 \%$ substrate(Gelatin) concentration; $24 \mathrm{~h}$ incubation period; $32^{\circ} \mathrm{C}$ incubation temperature and $6.0 \mathrm{pH}$; the best buffer for production of STP enzyme was phosphate buffer. The best broth ingredient was tryptone; An optimum carbon sources was glucose; an optimum nitrogen source for STP enzyme production was tryptone; Valine was the best amino acids for the production of STP enzyme; the utilization of organic acids, acetic, citric, lactic acid decreased STP enzyme production at different concentrations above 3.0\%. The STP enzyme was partially purified by ammonium sulfate precipitation and dialysis. The enzyme was found to have $52 \mathrm{KDa}$ molecular weight by SDS - PAGE analysis. The STP enzyme activity increased as the increase in enzyme concentration. The data obtained emphasizes the possibility of production and purification of the microbial STP enzyme for application under industrial scale.
\end{abstract}

Keywords: Serratiopeptidase, Production, Characterization and Serratia marcescens

\section{Introduction}

The proteolytic enzymes in common use today is derived from bacteria (serrapeptase grown from Serratia marcescens cultures), plants (bromelain from pineapple stem and papain from papaya), and animal sources (trypsin and chymotrypsin from hogs or cattle). They're all generally useful, but for many applications serrapeptase appears to be the most useful of them all. Serrapeptase was compared to trypsin, chymotrypsin, and pronase (another microbial peptidase) in a rat model of scalding, which is known to induce abnormal activation of fibrinolysis. Serrapeptase was far more effective than any other enzyme in repressing fibrinolysis in this model, in agreement with its documented clinical efficacy as an anti-inflammatory agent (Braun and Sutherland, 2003).

Serratiopeptidase is a proteolytic enzyme available for clinical use more than a decade. Serratiopeptidase binds to alpha -2-macroglobulin in the blood in the ratio of 1:1,

which helps to mask its antigenicity but retains its enzymatic activity and is slowly, transferred to site of inflammation. Serratiopeptidase hydrolyses bradykinin, histamine and serotonin responsible for the oedematic status. Serratiopeptidase reduces swelling, improves microcirculation and expectoration of sputum, etc.

The controlled fermentation of Serratia sp. secretes serratiopeptidase enzyme in the highly selective medium. The recovery process involves various types of filtration, concentration and steps to make enzyme useful for pharmaceutical applications.

The knowledge of production, purification and characterization of serratiopeptidase is very important for improvising the activity and the commercial value of the enzyme.

\section{Materials and Methods}

\section{Microorganism and inoculum preparation}

A culture of Serratia marcescens previously isolated from soil was identified by standard method for bacterial identification and was selected for STP production. Stock cultures were maintained in nutrient broth medium with 
$70 \%$ glycerol. A loopful of bacterial strain (Serratia marcescens) were transferred to a tube of sterile trypticase soy broth and allowed to grow overnight at $32^{\circ} \mathrm{C}$ before being used for fermentation.

\section{Fermentation procedure}

STP crude enzyme was produced by fermentation of the trypticase soy broth \{production medium (PM)\} which was autoclaved at $121^{\circ} \mathrm{C}$ for 15 min before inoculation with Serratia marcescens. The contents of the flasks were mixed thoroughly and then incubated for $24 \mathrm{~h}$ at $32{ }^{\circ} \mathrm{C}$ for enzyme production.

\section{Extraction of STP enzyme}

The whole contents of fermented broth containing STP enzyme were centrifuged at 10,000 rpm for 20 minutes and the supernatant was filtered through whatman no. 1 filter paper and then through membrane filter. The cell free filtrate was used as the enzyme source. The extracted volume was then preserved in the refrigerator at $4{ }^{\circ} \mathrm{C}$ and used as a crude STP enzyme source (Ammar et al.,1985).

\section{Enzyme assay:}

\section{Gelatin clearing zone technique}

The STP enzyme activity was determined according to gelatin clearing zone (GCZ technique of Elwan et al.,1986 standardized later by Ammar et al., 1998). In this assay, soluble gelatin (1\% w/v) was emulsified and supplemented with $(1.5 \% \mathrm{w} / \mathrm{v})$ bacto-agar. $\mathrm{pH}$ was adjusted as required with proper buffer (e.g. phosphate buffer at $\mathrm{pH}$ 7.0). Cups (wells) were made (3 cups optimal) in each plate. Equal amounts ( $0.1 \mathrm{ml}$ suitable) of extracted enzyme (or enzyme solution) to be assayed were introduced into each cup. The plates were incubated at $35^{\circ} \mathrm{C}$ for $24 \mathrm{~h}$. At the end of incubation time, the plates were flooded with previously prepared mercuric chloride $(\mathrm{HgCl})$ in $\mathrm{Hcl}$ solution ( $\mathrm{HgCl}, 15 \mathrm{~g}$ and $20 \mathrm{ml}$ of $6 \mathrm{~N} \mathrm{Hcl}$ completed to $100 \mathrm{ml}^{-1}$ with distilled water) (Cowan, 1974), and the mean diameters of gelatin clearing zones were calculated. The enzyme production was then expressed in terms of units/ml using a special standard curve constructed for such a purpose (Ammar et al, 1998).

\section{Optimization of STP production}

\section{a. Different substrate (gelatin) concentrations}

The effect of different gelatin concentrations $\left(\mathrm{g} / 1^{-1}\right)$ on enzyme production was performed using $0.1,0.2,0.3,0.4$, $0.5,0.6,0.7,0.8,0.9,1.0,1.5$ and $2.0 \%(\mathrm{w} / \mathrm{v})$ of gelatin and then incubated for $24 \mathrm{~h}$ at $32^{\circ} \mathrm{C}$.

\section{b. Incubation temperature}

Serratia marcescens was grown in production medium and incubated at different incubation temperatures viz.: 20 , $24,28,32,36,37,40$ and 44 respectively.

\section{c. Different pH values}

Phosphate buffer were prepared at different $\mathrm{pH}$ values, 4,5,6,7,8,9 and10. The production medium was adjusted using a standard $\mathrm{pH}$ meter for the above $\mathrm{pH}$ separately using the buffer prepared. The effect of $\mathrm{pH}$ on STP production was then studied.

\section{d. Incubation period}

The effect of incubation period was determined by incubating production medium for different incubation periods viz. $6,12,18,24,28,32,36,40$ and $44 \mathrm{~h}$ at $32^{\circ} \mathrm{C}$. Other experimental conditions were maintained for normal standards in each of the above case.

\section{e. Elimination of one or more of the ingredients}

The three ingredients of production (trypticase soy broth) medium(tryptone, glucose and yeast extract) were subjected to a process of elimination of one of the ingredients. Then it was incubated for $24 \mathrm{~h}$ at $32^{\circ} \mathrm{C}$.

\section{f. Different carbon sources}

Different carbon sources maltose, sucrose, glucose, lactose, mannitol and xylose was prepared at an equimolecular carbon level and were supplemented separately as the only carbon sources in the production medium. A control represented by production medium without any carbon source was also performed.

\section{g. Different nitrogen sources}

Ammonium sulphate, peptone and tryptone were added at equimolecular nitrogen content to the production medium and they were used as the only nitrogen source.

\section{h. Different amino acids}


This experiment was done to investigate the effect of different amino acids on STP production. $1.0 \mathrm{mg}$ of different amino acids (arginine, proline, leucine, glycine, valine and tryptophan) were supplemented into the production medium.

\section{i. Different organic acids}

The effect of organic acids on STP enzyme production was studied using different organic acids like lactic acid, acetic acid, and citric acid at individual concentrations ranging from $0.1 \%$ to $3.0 \%$ in the production medium.

\section{Enzyme production and purification}

STP production and purification included the following steps:

\section{Enzyme production and preparation of cell free filtrate}

Serratia marcescens was grown under optimized conditions in trypticase soy broth. The broth was centrifuged at $10000 \mathrm{rpm}$ for $20 \mathrm{mins}$ at $4^{\circ} \mathrm{C}$ in order to obtain a cell free filtrate (CFF). The CFF was filtered through whatman filter paper no. 1 and then subsequently through a membrane filter. After performing a test for sterility, $200 \mathrm{ml}$ of the cell free filtrate (CFF) containing STP enzyme were collected and their proteolytic activities and protein content were determined.

\section{Ammonium sulfate fractionation}

$200 \mathrm{ml}$ of the crude STP enzyme were first brought to $20 \%$ (w/v) saturation with solid ammonium sulfate (enzyme grade) according to the chart of Gomori (1955) as mentioned by Dixon and Webb (1964). The precipitated proteins were separated by centrifugation for $15 \mathrm{~min}$ at $500 \mathrm{rpm}$. The resultant pellet was dissolved in $5 \mathrm{ml}$ of phosphate buffer at $\mathrm{pH}$ 7.0. The left supernatant was applied again with ammonium sulfate to achieve 20, 40, 60, 80, and $100 \%(\mathrm{w} / \mathrm{v})$ saturation. Both enzyme activity and protein content were determined for each separate fraction.

\section{Dialysis against distilled water and buffer}

The obtained ammonium sulfate precipitate (in solution) was introduced into special plastic bag for dialysis against distilled water for $3 \mathrm{~h}$, followed by dialysis against phosphate buffer at $\mathrm{pH}$ 7.0. The dialyzed STP enzyme preparation was stored in the refrigerator at $5^{\circ} \mathrm{C}$ for further purification.

\section{Enzyme activity}

The STP enzyme activity was determined as previously mentioned by El-Safey and Ammar, (2002).

\section{Determination of molecular weight by SDS PAGE analysis}

The purified STP enzyme was subject to sodium dodecyl sulphate- poly acrylamide gel electrophoresis (SDS-PAGE) (Ronnle Machielsen et al., 2005) with lower separating gel (pH 8.8), upper stacking gel (pH 6.8) and $16.6 \%$ acrylamide concentration. A broad range protein molecular weight marker - (Medox- MX -0211-01) was used to compare with the purified STP enzyme for the determination of the molecular weight of STP and confirmation of the enzyme.

\section{Results}

\section{Serratiopeptidase(STP) production}

The extracellular STP enzyme was synthesized by Serratia marcescens. The results obtained in this work revealed the ability of Serratia marcescens to produce extracellular STP enzyme. Different growth conditions were established to optimize and obtain the maximum levels of STP enzyme productivity by Serratia marcescens.

\section{Optimization of STP production}

The gelatin clearing zone (GCZ) exhibited by the STP produced from Serratia marcescens showed maximum STP enzyme production with a clearing zone of $36 \mathrm{~mm}$ at an incubation period of $24 \mathrm{~h}$ (Table 1.0).

The effects of different incubation temperatures on STP enzyme production were evaluated. It is obvious from the results in Table 1.1 that $32{ }^{\circ} \mathrm{C}$ was generally more favorable for STP enzyme production producing 36mm GCZ. However, the temperature below or above $32{ }^{\circ} \mathrm{C}$ caused a sharp decrease in STP yield.

Different substrate (gelatin) concentrations were applied for investigating their effect on STP enzyme productivity by Serratia marcescens. Data (Table 1.2) indicated that the maximum productivity was attained at a gelatin concentration of $0.5 \%(\mathrm{w} / \mathrm{v})$ producing $35 \mathrm{~mm}$ GCZ. Higher or lower concentrations of gelatin resulted in a notable decrease in STP enzyme productivity.

An experiment was designed to investigate the effect of different carbon sources on STP enzyme production by Serratia marcescens. The result in Table 1.3 showed that the best carbon source for STP enzyme production was 
glucose. When the Serratia marcescens used glucose as a carbon source, the STP enzyme production reached to the maximum producing $35 \mathrm{~mm}$ GCZ. The other carbon sources gave weak or no STP enzyme production.

Table 1.4 shows the results of different nitrogen sources in relation to STP enzyme production by Serratia marcescens. Different organic and inorganic nitrogen source were used. The best nitrogen source for STP enzyme production was tryptone producing $34 \mathrm{~mm} \mathrm{GCZ}$.

Data (Table 1.5) show that various amino acids incorporated separately into production medium in absence of any other nitrogen sources except gelatin succeeded to promote STP enzyme productivity by Serratia marcescens. Two amino acids (glycine and valine) out of six amino acids under investigation gave stimulatory effects concerning STP enzyme production in comparison to the control and other amino acids under investigation. However, the best amino acid for STP enzyme production was valine producing $35 \mathrm{~mm}$ GCZ.

The effect of elimination of one of the ingredients in production medium for STP enzyme production by Serratia marcescens was performed. Data indicated that, STP enzyme reached its maximum productivity, when both tryptone and yeast extract were introduced into production medium when glucose was eliminated(Table 1.6).

Different organic acid, lactic, citric and acetic acids were incorporated in production medium to investigate their effects on STP enzyme production by Serratia marcescens. The results (Table 1.7a,b,c) indicated that all organic acids applied have stimulatory effect to STP enzyme production from concentrations 0.1 to $1.5 \%(\mathrm{w} / \mathrm{v})$. On the other hand, when increase acids concentrations gave inhibitory effects on production of STP enzyme. When different acids were incorporated to production medium, at $1.5 \%$ to $3.0 \%$ concentrations there is no STP enzyme production.

The production medium was adjusted to different $\mathrm{pH}$ values using phosphate buffer of different $\mathrm{pH}$. Results (Table 1.8)) indicated that the best buffer was phosphate buffer and optimum $\mathrm{pH}$ for production of STP was recorded at 6.0 with $36 \mathrm{~mm}$ GCZ. A notable decline in the enzyme productivity occurred at both higher and lower $\mathrm{pH}$ values.

\section{Ammonium sulphate precipitation of STP}

The culture supernatant of Serratia marcescens containing an initial STP activity

(210.56 units $/ \mathrm{ml}$ ) was concentrated by ammonium sulfate precipitation. The optimum ammonium sulfate fractionation was $40 \%(\mathrm{w} / \mathrm{v})$ saturation. It showed increase in specific activity $(1004.3712 \mathrm{units} / \mathrm{ml})$ up to 4.77 times compared to the un concentrated supernatant (Table2.0).

\section{Dialysis}

The STP was subjected to dialysis against sucrose which resulted in an increase of enzyme activity to 1450.7584 (units $/ \mathrm{ml}$ ). This gave an increase of enzyme activity up to 6.89 times(Table 2.0).

\section{SDS- PAGE analysis of STP}

The STP enzyme was viewed as a major separating protein on the electrophoresed poly acrylamide gel stained with coomassie brilliant blue along with other minor protein impurities as the enzyme was not fully purified. On comparison with the protein molecular weight marker the STP was found to have a molecular weight of approximately around 52KDa (Plate 1.0).

\section{Discussion}

\section{STP production}

Data obtained clearly indicates that Serratia marcescens produces STP enzyme. The optimal conditions for STP production have been determined under bench scale fermentation conditions.

The present study indicated that the optimum incubation period for STP production was $24 \mathrm{~h}$ (Table 1.0).

Myhara and Skura, (1990) investigated optimization of cultural conditions affecting the production of extracellular proteinase by Pseudomonas fragi ATCC 4973 and reported that the optimum incubation period for proteinase production by Ps. fragi was 38 h. However, Abdul-Raouf (1990) reported that both Bacillus anthracis, S-44 and Bacillus cereus var. mycoides S-98 exhibited their maximum ability to biosynthesize proteases within $24 \mathrm{~h}$ incubation period since the productivity reached up to 126.09 units $/ \mathrm{ml}$ for Bacillus anthracis S-44 corresponding to 240.45 units/ml for Bacillus cereus var. mycoides S-98 respectively. Moreover, Johnvesly et al., (2002), found that a high level of extracellular thermostable protease activity was observed after $24 \mathrm{~h}$ incubation.

The maximum enzyme yield of $930 \mathrm{I} . \mathrm{U} / \mathrm{ml}$ (about 3 -fold increase) was obtained with $48 \mathrm{hrs}$ inoculum (Ellaiah and Srinivasulu 1996). 
In a study on the production of proteases and lipases by three strains of psychrophilic Pseudomonas spp in whole milk, Stead, (1987) found a short lag period following inoculation before the growth of cultures. In the same study (Stead, 1987), protease production by P. fluoresenscens and P. fargi began at $10^{\text {th }}$ day of incubation and increased rapidly throughout at 50 days of incubation period.

The maximum STP productivity was attained in the presence of gelatin concentration of $0.5 \%(\mathrm{w} / \mathrm{v})$. Abdul- Raouf (1990), reported that the maximum protease productivity was attained at a gelatin concentration of $1 \%(\mathrm{w} / \mathrm{v})$ for Bacillus anthracis S-44, and 1.5-2 \% (w/v) for Bacillus cereus var. mycoides S-98.

The results indicated that the optimum temperature for STP enzyme productivity by Serratia marcescens was 32 ${ }^{\circ} \mathrm{C}$. Many investigators have studied the relation of temperatures and enzyme production. The temperature ranging from $2-70^{\circ} \mathrm{C}$ or more depends on the type of organism, the medium conditions and the type of enzyme. Secades, et $a$ l., (2001), observed the same results that the optimum temperature for an extracellular protease produced by Flavobacterium psychrophilum was at temperatures between 25 and $40{ }^{\circ} \mathrm{C}$. In addition to that, the optimum temperature for protease production was between 30 and $45^{\circ} \mathrm{C}$ (Wery, et al., 2003). Jobin and Grenier (2003) investigated the production of proteases by Streptococcus suis serotype 2 and recorded that the optimum temperature for protease production ranged from 25 to $42{ }^{\circ} \mathrm{C}$.

In view of the data of the other investigators, growth and extracellular proteinase production by Enterococcus faecalis subsp. liquefaciens was studied on several culture media and under different incubation conditions. The optimum temperature for production of proteinase was $37^{\circ} \mathrm{C}$. However, proteinase production was not affected by temperature in the range of $7-45^{\circ} \mathrm{C}$ (Garcia de Fernando, et al., 1991). In addition to that, a Pseudomonas sp. produced an extracellular thermostable protease. Growth of the organism and the production of protease was optimum at $30^{\circ} \mathrm{C}$. (Chakraborty and Srinivasan, 1992).

Under conditions of submerged fermentation of Bacillus licheniformis strain L-3 in 15-L MBR-Schulzer bioreactor, the maximum production of proteolytic enzymes was good up to a temperature stability (65 $\left.{ }^{\circ} \mathrm{C}\right)$ (Michalik et al., 1997). Joo, et al., (2003) reported that alkaline protease secreted by Bacillus clausii of industrial significance had an optimum temperature of $60^{\circ} \mathrm{C}$. Similarly, Johnvesly et al., (2002), reported that the optimum temperature for protease activity were $70^{\circ} \mathrm{C}$ produced by thermo alkalophilic Bacillus sp. JB-99.

Certain carbohydrates were introduced as carbon sources into the production medium of STP biosynthesis by Serratia marcescens. The present results indicated that the glucose was the best carbon source that induced the production of STP by Serratia marcescens on production medium and reached to the maximum productivity. The same finding were reported by Yang, et al., (1999), who studied the effect of carbon sources on the production of protease by Bacillus subtilis growing in shrimp and crab shell powder medium containing one of the additional carbon sources; glucose, lactose, carboxymethyl cellulose, $\mathrm{D}(-)$ arabinose, $\mathrm{D}(+)$ xylose, and rice bran. They found that protease production was greatly enhanced by the the addition of lactose or arabinose into the medium and that $1 \%(\mathrm{w} / \mathrm{v})$ arabinose was the most effective substrate and concentration for protease production.

Phadatare et al., (1993) evaluated various sugars such as glucose, lactose, maltose, sucrose, xylose, and sugar alcohols, glycerol, mannitol, and sorbitol for their effect on protease production. The results obtained revealed that sucrose gave maximum protease activity. Moreover, Andrade et al., (2002) found that the protease production reached to the maximum when D-glucose was supplemented to the medium especially when used at low concentrations $(40 \mathrm{~g} / 1)$. In contrast, a recent investigation showed that protease from Streptomyces ambofaciens was detected only after glucose depletion (Benslimane et al., 1995).

Some investigators have reported that glucose has been reported to suppress protease production (Sen and Satyanarayana, 1993 and Sonnleitner, 1983). Madzak et al., (2000) showed that the sucrose is good substrate for production extracellular proteases. Actually, the production of two extracellular proteases, an endopeptidase and an aminopeptidase, by the marine bacterium Vibrio SA1 was studied in batch cultures. It was supplemented with easily metabolisable carbon compounds such as glucose, lactate and succinate during growth in peptone media (Wiersma et al., 1978).

The results indicated that the best nitrogen source for STP production by Serratia marcescens was tryptone. Several investigators have studied the effect of nitrogen sources on enzyme productivity. Marine Pseudomonas strain 1452 having the ability to produce extracellular protease uses casein, as the nitrogen and carbon source (Makino, et al, 1981). Nigam et al, (1981), reported that, a strain of Pseudomonas aeruginosa from soil produced large quantities of extracellular neutral proteinase and could utilize several organic substances as carbon and nitrogen sources for enzyme production. The growth media required the presence of a high amount of phosphate when glucose was the carbon source. The acid intermediates of citric-acid cycle supported the proteinase 
production more than any other carbon sources. However, complex nitrogenous substances supported enzyme production more efficiently. Higher concentration of amino acids suppressed the proteinase synthesis.

An extra cellular protease having the activity of coagulase was synthesized by Bacillus subtilis var. amyloliquefaciens when the growth medium contained no nitrogen sources. The removal of a nitrogen source from the medium was found to induce the synthesis of exo proteases by washed bacterial cells (Cherdyntseva, et al, 1982).

The effect of elimination of the ingredients of production medium (PM) on the productivity of STP enzyme by Serratia marcescens was undertaken. Data indicated that, STP reached its maximum productivity when both tryptone and yeast extract were introduced into production medium.

The results indicated that various amino acids incorporated separately into production medium in absence of any other nitrogen sources except gelatin succeeded to promote STP enzyme productivity by Serratia marcescens. The best amino acid for STP enzyme production was valine.

Our results indicated that all organic acids applied have stimulatory effect to STP enzyme production from concentrations 0.1 to $1.5 \%$. Increase in the acids concentration gave inhibitory effects on production of STP enzyme.

The production medium was adjusted to different $\mathrm{pH}$ values using phosphate buffer of various $\mathrm{pH}$. Results indicated that the best $\mathrm{pH}$ for production of STP was at $\mathrm{pH} 6.0$ in phosphate buffer with maximum STP productivity. Similarly, the optimal $\mathrm{pH}$ of protease activity produced by Clostridium bifermentans NCTC 2914 was 7.0. (Macfarlane and Macfarlane, 1992). Moreover, investigating the production of proteases by S. suis serotype 2, proteases were identified and characterized using chromogenic and fluorogenic assays and zymography. The optimum pH for all four proteases were between 6 and 8 (Jobin and Grenier, 2003). In view of the data of the other investigators, Johnvesly et al, (2002) reported that, a high level of extra cellular thermostable protease activity produced by thermoalkaliphilic Bacillus $s p$. JB-99 was observed at $\mathrm{pH} 11$. So this enzyme showed stable activity under alkaline conditions. The production and properties of protease from Bacillus sphaericus strain C3-41 showed optimal activities of the protease around $\mathrm{pH} 11.0$. The enzyme was stable at $\mathrm{pH}$ 5.0-12.0(Sun et al, 1997).

\section{Purification of STP enzyme}

STP enzyme was purified by ammonium sulfate precipitation and dialysis as mentioned by El-Safey and Ammar, (2003). A trial for the purification of STP enzyme resulted in enzyme activity of 1450.7584 (units $/ \mathrm{ml}$ ) after dialysis of the enzyme sample. Ammonium sulphate precipitation with $40 \%$ saturation had the maximal enzyme activity of 1004.3712 units/ml which was 4.77 times more than the crude STP (Table 2.0).

The same method were used for purification of thermostable protease produced by B. brevis geltinoamylolyticus attacked fish wastes and poultry wastes. The thermostable protease were purified by applying ammonium sulphate fractionation and sephadex G200 and G100 column chromatography, where specific activity $44562.5 \mathrm{units} / \mathrm{ml}-1$ protien $/ \mathrm{ml}-1$ with purification folds of 8.5 times for sehphadex G200 and 69017.5 units $/ \mathrm{ml}-1$ protien $/ \mathrm{ml}-1$ with purification folds 13.18 times for sephadex G100 (Ammar, et al, 2003).

\section{Properties of the purified protease enzyme}

The present result indicated that as STP concentration increased the STP activity increases. This behavior is in accordance with the observations of West, et al. (1967) who stated that within fairly wide limits the speed of enzyme concentration is directly proportional to the enzyme concentration. The same finding also reported by Abd El-Rahman, (1990); El-Safey, (1994); El-Safey and Ammar, (2003). The STP activity reached to the maximum with optimum substrate (gelatin) concentration $0.5 \%(\mathrm{w} / \mathrm{v})$. Increase or decrease of substrate concentration below optimal levels decreased the STP enzyme activity.

\section{Molecular mass of STP}

The molecular weight was in correspondence with about approximately $52 \mathrm{KDa}$ which is the molecular weight of the standard STP as demonstrated in SDS-PAGE (Fig 1.0) (Ronnle Machielsen et al., 2006). The result is an indication of the confirmed production of STP enzyme and the molecular weight determination completes the characterization of the enzyme.

\section{References}

Abdul-Raouf U. M. (1990). Studies of proteolytic bacteria isolated from certain localities in Aswan city. A thesis (MSc.), Botany and microbiology Department, Faculty of Science, Al-Azhar University, Cairo. 
Abd El-Rahman, E. M. (1990). Studies on Some Thermophlic Bacterial Strains. Ph.D. Thesis, Al-Azhar Univ., Fac. Of Sci., Bot.and Microbiol. Dept., Cairo, Egypt.

Aleksieva, P. and Peeva, L. (2000). Investigation of acid protinase biosynthesis by the fungus Humicola Lutea 120-5 in an airlift bioreactor. Enzyme Microb. Technol., 26: 402-405.

Ammar M. S. (1975). Studies on Thermophilic Bacteria. Ph.D., Thesis, Botany Department, Faculty of Science, Al-Azhar University, Cairo, Egypt.

Ammar, M. S.,El-Ssaway, M.; Yassin, M. and Sherif, Y. M. (1998). Hydrolytic Enzymes of fungi isolated from Certain Egyptian Antiquities objects while utilizing the Industrial Wastes of Sugar and Integrrated Industries Company (SIIC), Egypt. J. Biotechnol., (3): 60-90.

Ammar M. S., Bayoumi R. A., El-Kasaby A. M. H and Soliman A. M. (2003). Purification and properties of thermostable protease by B. brevis geltinoamylolyticus using fish wastes (Fi.W.) and poultry wastes (Po.W) under solid state fermentation (S.S.F.) conditions. 5 th Int. Sic. Conf. Al-Azhar Univ. Fac. Sci. March 25-27, 2003 Cairo, Egypt. Pp.54.

Andrade, V. S., Sarubbo, L. A., Fukushima, K., Miyaji, M., Nishimura, K. And de Campos-Takaki, G. M., (2002). Production of extracellualr proteases by Mucor circinelloides using D-glucose as carbon sources/substrate. Brazilian Journal of Microbiogy, 33: 106-110.

Berla Thangam E. and Suseela Rajkumar G. (2002). Purification and characterization of alkaline protease from Alcaligenes faecalis Biotechnol. Appl. Biochem., 35, 149-154.

Boyer, H. W. and Carlton. B. C. (1968). Production of two proteolytic enzymes by a transformable strain of Bacillus subtilis. Arch. Biochem. Biophys, 128:442- 455.

Braun P., and Sutherland J. P. (2003). Predictive modelling of growth and enzyme production and activity by a cocktail of Pseudomonas spp., Shewanella putrefaciens and Acinetobacter sp. Int J Food Microbiol. 86(3):271-82.

Chakraborty R. and Srinivasan M. (1992). Production and regulation of a thermostable protease by Pseudomonas sp. B45. Acta Microbiol Hung, 39(2):181-91.

Cherdyntseva T.A., Razin'kov V. K. and Egorov N. S. (1982). Bacillus subtilis var. amyloliquefaciens biosynthesis of extracellular protease possessing coagulase activity and formed under conditions of limiting the nitrogen sources in the medium. Mikrobiologiia., 51(3):431-5.

Cowan, S. T. (1974). Cowan and Steel's Manual For The Identification of Medical Bacteria. 2 nd Ed. Cambridge, Univ. Press, London.

Daguerre, K. Cuevase, C. M. Mazza, L. A. and Balatti, A. P. (1975). Alkaline protease production. Rev. Asoc. Argent. Microbiol, 7(2), 49-55.

Dixon M. and Webb, E. G. (1964). Enzyme, 2 nd Edit. Academic Press. Inc. New York.

Ellaiah P. and Srinivasulu B. (1996). Production of extracellular protease by Streptomyces fradiae. Hindustan Antibiot Bull, 38(1-4):41-7.

El-Safey, E. M. (1994). Production of microbial I-amylases under solid-state incubation conditions in the open air. (MSc) A thesis, Bot. and Microbiol. Dept., Fac. Sci., Al-Azhar Univ., Cairo, Egypt.

El-Safey E. M. and Ammar M.S., (2002). Amylase production using Nile hyacinth under solid state fermentation (SSF) conditions. Int. Conf. for Develop. and the Env. In the Arab World, Assiut Univ., March 26-28, 2002, pg. 101-113.

El-Safey E. M. and Ammar M. S. (2003). Purification and characterization of NH- L-amylase isolated from Aspergillus flavus var. columnaris. International Confernces Of Enzymes In The Environment, Activity, Ecology And Applications, Praha, Czech Republic, July 14-17, 2003. pg 127.

Jobin MC, and Grenier D. (2003). Identification and characterization of four proteases produced by Streptococcus suis. FEMS Microbiol Lett., 14;220(1):113-9.

Joo H. S., Kumar C. G., Park G. C., Paik S. R. and Chang CS. (2003). Oxidant and SDS-stable alkaline protease from Bacillus clausii I-52: production and some properties. J Appl Microbiol, 95(2):267-72.

Kohlmann K. L., Nielsen S. S., Steenson L. R. and Ladisch M. R. (1991). Production of proteases by psychrotrophic microorganisms. J. Dairy Sci., 74:3275-3283. 
Kunst, F., Pascal, M. L., Lepesant-Kejzlarova, J., Lepesant, J.-A., Billault, A. and Dedonder, R. (1974). Pleiotropic mutations affecting sporulation conditions and the synthesis of extracellular enzymes in Bacilhu subtilis 168. Biochemie, 66:1481-1489.

Garcia de Fernando G. D., Hernandez P. E., Burgos J., Sanz B., and Ordonez J. A. (1991). Extracellular proteinase from Enterococcus faecalis subsp. liquefaciens. I. Growth and extracellular proteinase production under different culture conditions. Folia Microbiol (Praha).36(5):423-8.

Gibb, G. D. and Strohl, W. R. (1987). Physiological regulation of protease activity in Streptomyces peucetius. Can. J. Microbiol, 34: 187-190.

Gomori, G. (1955). Preparation of buffers for use in enzyme active studies. In methods in enzymology. Vol. I. Eds. (Colwick, S. P. and Kaplan, N. O.).

Gupta, R., Beeg QK. and Loranz P. (2002a). Bacterial alkaline proteases: molecular approaches and industrial applications. Appl. Microbiol. Biotechnol., 59(1):15-32.

Gupta, R.; Beeg Q. K.; Khan S. and Chauhan, B., (2002b). An overview on fermentation, downstream processing and properties of microbial alkaline proteases. Appl. Microbiol. Biotechnol., 60(4): 381-395.

Lee C. Y., Cheng M. F., Yu M. S. and Pan M. J. (2002). Purification and characterization of a putative virulence factor, serine protease, from Vibrio parahaemolyticus. FEMS Microbiol Lett. 19;209 (1):31-37.

Macfarlane G. T., and Macfarlane S. (1992). Physiological and nutritional factors affecting synthesis of extracellular metalloproteases by Clostridium bifermentans NCTC 2914. Appl.Environ. Microbiol, 58(4):1195-1200.

Madzak C., Treton B. and Blanchin-Roland S. (2000). Strong hybrid promoters and integrative expression/secretion vectors for quasi-constitutive expression of heterologous proteins in the yeast Yarrowia lipolytica. J.Mol.Microbiol.Biotechnol, 2 (2):207-16.

Makino K., Koshikawa T., Nishihara T., Ichikawa T. and Kondo M. (1981). Studies on protease from marine bacteria. 1 Isolation of marine Pseudomonas sp 145-2 and purification of protease. Microbios, 31(124):103-12.

Massucco, A. E. (1980). Production of alkaline protease from Bacillus subtilis NRRL 3441. Rev. Argent. Microbiol., 12(2), 52-58. C.F.C.A., 94(21), 172849R (1981).

McConn, J. D., Tsuru, D. and Yasunobu. K. T. (1964). Bacillus subtilis neutral proteinase. I. A zinc enzyme of high specific activity. J. Biol. Chem., 239:3706-3715.

Mckevitt, A I., Bajaksouzian, S., Klinger, J. D. and Woods, D. E. (1989). Purification and characterization of an extracellular protease from Pseudomonas cepacia. Infection and Immunity, 57 (3): 771-778.

Michalik I., Szabova E., Polakova A. and Urminska D. (1997). Bacterial proteases: production, isolation and utilization in animal nutrition. Ukr Biokhim Zh., 69(3):28-35.

Millet, J., M. Larribe, and J.-P. Subert. (1976). Mutant thermosensible de B. subtilis affecté dans la sporulation et al sérylprotéase extracellulaire. Biochimie, 58:109-117.

Myhara R. M., and Skura B. (1990). Centroid search optimization of cultural conditions affecting the production of extracellular proteinase by Pseudomonas fragi ATCC 4973. J. Appl. Bacteriol, 69(4):530-8.

Nigam J. N., Pillai K. R. and Baruah J. N. (1981). Effect of carbon and nitrogen sources on neutral proteinase production by Pseudomonas aeruginosa. Folia Microbiol (Praha). 26(5): 358-363.

Phadatare, S. U., Deshpande, V. V. and Srinivasan, M. C. (1993). High activity alkaline protease from Conidiobolus coronatus (NCL 86.8.20). Enzyme production and compatibility with commercial detergents. Enzyme Microbiol. Technol., 15:72-76.

Priest, F. G., (1977). Extracellular enzyme synthesis in the genus Bacillus. Bacteriol. Rev., 41:711-753.

Rappaport, H. P., Riggsby, W. S. and Holden. D. A. (1965). A Bacillus subtilis proteinase. I. Production, purification and characterization of a proteinase from a transformable strain of Bacillus subtilis. J. Biol. Chem., 240:78-86.

Remeikaite, I. (1979). Biosynthesis extracellular metallo protease during the growth of Bacillus subtilis culture. Mikrobiol. Proizoud., 6 th C.F.C.A. 97(5), 3575g. 
Ronnle Machielsen, Augustinus, R. Uria, Serve, W.M Kengen and John Van der Oost. (2006). Production and Characterization of a themostable Alcohol dehydrogenase. That Belongs to the Aldo-keto Reductase Super Family. App and Environ Microbiol, 72: P233-238.

Secades P.; Alvarez B. and Guijarro J. A., (2001). Purification and characterization of a psychrophilic, calcium-induced, growth-phase-dependent metalloprotease from the fish pathogen Flavobacterium psychrophilum. Appl. Environ. Microbiol, 67(6):2436-2444.

Secades P, and Guijarro J. A. (1999). Purification and characterization of an extracellular protease from the fish pathogen Yersinia ruckeri and effect of culture conditions on production. Appl. Environ Microbiol, 65(9):3969-3975.

Sen S., and Satyanarayana, T., (1993). Optimization of alkaline protease production by thermophilic Bacillus licheniformis S-40. Ind. J.Microbil., 33:43-47.

Sharipova M. R., Shakirov E. V., Balaban N. P., Gabdrakhmanova L. A., Shilova M. A., Rudenskaia G. N., and Leshchinskaia I. B. (2000). Localization of proteolytic enzymes in cells of Bacillus intermedius. Mikrobiologiia. 69(5):660-667.

Snedecor, G. W. and Cochran, W. G. (1980). Statical methods. Lowa State University Press, Ames, IA. 428p.

Stead D., (1987). Production of extracellular lipases and protinases during prolonged growth of strains of psychrotrophic bacteria in whole milk. J. dairy Res., 54:535.

Sun F., Liu E. and Zhang Y. (1997). The properties of protease from Bacillus sphaericus C3-41. Wei Sheng Wu Xue Bao. 37(5):397-400.

Uchida, K. Mogi, T. and Fukushima, O. (1972). Microbial production of protease, amylase and lipase. Japan. 7250.389. C.F. Chem. Abst., 79(25), 144876.

Wery N., Gerike U., Sharman A., Chaudhuri J. B., Hough D. W., and Danson M. J. (2003). Use of a packed-column bioreactor for isolation of diverse protease-producing bacteria from antarctic soil. Appl. Environ. Microbiol, 69(3):1457-64.

West, E. S., Tood W. R., Mason H. S., and Van Burggen J. T. (1967). Text book of biochemistry $4^{\text {th }}$ ed. MacMillan Co., N. Y. Collier MacMillan Ltd., London.

Wiersma M., Hansen T A., and Harder W. (1978). Effect of environmental conditions on the production of two extracellular proteolytic enzymes by Vibrio SA1. Antonie Van Leeuwenhoek. 44(2):129- 140.

Yang, J. K., Shih, I. L., Tzeng, Y. M. and Wang, S. 1. (1999). Production and purification of protease from Bacillus subtilis that can deprotienize crustacean wastes. Enzyme Microb. Technol., 26:406-413.

Yoneda, Y., and B. Maruo. (1975). Mutation of Bacillus subtilis causing hyperproductivity of a-amylase and protease, and its synergistic effect. J. Bacteriol., 124:48-54.

Table 1.0 Effect of Incubation period on serratiopeptidase(STP) production

\begin{tabular}{|c|c|c|}
\hline S.NO & $\begin{array}{c}\text { Different incubation period } \\
\text { (hours) }\end{array}$ & $\begin{array}{c}\text { GCZ } \\
\text { (mm) }\end{array}$ \\
\hline 1 & 6 & 7 \\
\hline 2 & 12 & 16 \\
\hline 3 & 18 & 20 \\
\hline 4 & 24 & 36 \\
\hline 5 & 28 & 35 \\
\hline 6 & 32 & 34 \\
\hline 7 & 36 & 32 \\
\hline 8 & 40 & 32 \\
\hline 9 & 44 & 30 \\
\hline
\end{tabular}

GCZ- Gelatin clearing zone 
Table 1.1 Effect of incubation temperature on STP production

\begin{tabular}{|c|c|c|}
\hline S.NO & $\begin{array}{c}\text { Different incubation temperature } \\
\text { c) }\end{array}$ & $\begin{array}{c}\text { GCZ } \\
(\mathbf{m m})\end{array}$ \\
\hline 1 & 20 & 10 \\
\hline 2 & 24 & 17 \\
\hline 3 & 28 & 20 \\
\hline 4 & 32 & 36 \\
\hline 5 & 36 & 30 \\
\hline 6 & 37 & 30 \\
\hline 7 & 40 & 25 \\
\hline 8 & 44 & 18 \\
\hline
\end{tabular}

GCZ- Gelatin clearing zone

Table 1.2 Effect of different substrate (gelatin) concentrations on STP production

\begin{tabular}{|l|c|c|}
\hline S.NO & $\begin{array}{c}\text { Different substrate (gelatin) } \\
\text { concentrations (\%) }\end{array}$ & $\begin{array}{c}\text { GCZ } \\
(\mathbf{m m})\end{array}$ \\
\hline 1 & 0.1 & 11 \\
\hline 2 & 0.2 & 19 \\
\hline 3 & 0.3 & 22 \\
\hline 4 & 0.4 & 28 \\
\hline 5 & 0.5 & 35 \\
\hline 6 & 0.6 & 34 \\
\hline 7 & 0.7 & 20 \\
\hline 8 & 0.8 & 18 \\
\hline 9 & 0.9 & 10 \\
\hline 10 & 1.0 & 9 \\
\hline 11 & 1.5 & 9 \\
\hline 12 & 2.0 & 8 \\
\hline
\end{tabular}

GCZ- Gelatin clearing zone

Table 1.3 Effect of different carbon sources on STP production

\begin{tabular}{|l|c|c|}
\hline S.NO & Different carbon sources & $\begin{array}{c}\text { GCZ } \\
(\mathbf{m m})\end{array}$ \\
\hline 1 & Maltose & 19 \\
\hline 2 & Sucrose & 22 \\
\hline 3 & Glucose & 35 \\
\hline 4 & Lactose & No zone \\
\hline 5 & Mannitol & 21 \\
\hline 6 & Xylose & 24 \\
\hline 7 & Control(without carbon) & 18 \\
\hline
\end{tabular}


Table 1.4 Effect of different nitrogen sources on STP production

\begin{tabular}{|l|c|c|}
\hline S.NO & Different nitrogen sources & $\begin{array}{c}\text { GCZ } \\
(\mathbf{m m})\end{array}$ \\
\hline 1 & Ammonium Sulphate & 13 \\
\hline 2 & Peptone & 22 \\
\hline 3 & Tryptone & 34 \\
\hline 4 & Control(without nitrogen) & 10 \\
\hline
\end{tabular}

Table 1.5 Effect of different amino acids on STP production

\begin{tabular}{|l|c|c|}
\hline S.NO & Different aminoacids & $\begin{array}{c}\text { GCZ } \\
\text { (mm) }\end{array}$ \\
\hline 1 & Arginine & 23 \\
\hline 2 & Valine & 35 \\
\hline 3 & Tryptophan & 20 \\
\hline 4 & Proline & 16 \\
\hline 5 & Glycine & 32 \\
\hline 6 & Leucine & 19 \\
\hline 7 & Control(without amino acid) & 30 \\
\hline
\end{tabular}

GCZ- Gelatin clearing zone

Table 1.6 Effect of elimination of one ingredient in production media on STP production

\begin{tabular}{|l|c|c|}
\hline S.NO & $\begin{array}{c}\text { Elimination of one of the following } \\
\text { ingredients }\end{array}$ & $\begin{array}{c}\text { GCZ } \\
(\mathbf{m m})\end{array}$ \\
\hline 1 & Tryptone & 16 \\
\hline 2 & Yeast Extract & 18 \\
\hline 3 & Glucose & 29 \\
\hline
\end{tabular}

Table 1.7(a) Effect of different organic acids (lactic acid) on STP production

\begin{tabular}{|l|c|c|}
\hline S.NO & $\begin{array}{c}\text { Concentration of lactic acid } \\
(\mathbf{\%} \text { v/v })\end{array}$ & $\begin{array}{c}\text { GCZ } \\
(\mathbf{m m})\end{array}$ \\
\hline 1 & 0.1 & 32 \\
\hline 2 & 0.5 & 34 \\
\hline 3 & 1.0 & 33 \\
\hline 4 & 1.5 & 28 \\
\hline 5 & 2.0 & 07 \\
\hline 6 & 2.5 & No zone \\
\hline 7 & 3.0 & No zone \\
\hline
\end{tabular}


Table 1.7(b) Effect of different organic acids (acetic acid) on STP production

\begin{tabular}{|l|c|c|}
\hline S.NO & $\begin{array}{c}\text { Concentration of acetic acid } \\
(\% \mathbf{\%} / \mathbf{v})\end{array}$ & $\begin{array}{c}\text { GCZ } \\
(\mathbf{m m})\end{array}$ \\
\hline 1 & 0.1 & 30 \\
\hline 2 & 0.5 & 30 \\
\hline 3 & 1.0 & 28 \\
\hline 4 & 1.5 & 20 \\
\hline 5 & 2.0 & No zone \\
\hline 6 & 2.5 & No zone \\
\hline 7 & 3.0 & No zone \\
\hline
\end{tabular}

GCZ- Gelatin clearing zone

Table 1.7(c) Effect of different organic acids (citric acid) on STP production

\begin{tabular}{|l|c|c|}
\hline S.NO & $\begin{array}{c}\text { Concentration of citric acid } \\
(\% \mathbf{v} / \mathbf{v})\end{array}$ & $\begin{array}{c}\text { GCZ } \\
(\mathbf{m m})\end{array}$ \\
\hline 1 & 0.1 & 25 \\
\hline 2 & 0.5 & 30 \\
\hline 3 & 1.0 & 31 \\
\hline 4 & 1.5 & 29 \\
\hline 5 & 2.0 & No zone \\
\hline 6 & 2.5 & No zone \\
\hline 7 & 3.0 & No zone \\
\hline
\end{tabular}

Table 1.8 Effect of different $\mathrm{pH}$ on STP production

\begin{tabular}{|l|c|c|}
\hline S.NO & $\begin{array}{c}\text { Different pH } \\
\text { values }\end{array}$ & $\begin{array}{c}\text { GCZ } \\
(\mathbf{m m})\end{array}$ \\
\hline 1 & 4 & 9 \\
\hline 2 & 5 & 24 \\
\hline 3 & 6 & 36 \\
\hline 4 & 7 & 32 \\
\hline 5 & 8 & 15 \\
\hline 6 & 9 & 06 \\
\hline 7 & 10 & No zone \\
\hline
\end{tabular}

Table 2.0 Enzyme activity of crude and purified STP

\begin{tabular}{|c|c|c|c|c|}
\hline S.NO & Serratiopeptidase (STP) & $\begin{array}{c}\text { GCZ } \\
(\mathbf{m m})\end{array}$ & $\begin{array}{c}\text { Enzyme activity } \\
\text { Units/ml }\end{array}$ & Increase folds in STP production \\
\hline 1 & Crude STP & 24 & 210.56 & - \\
\hline 2 & $20 \% \mathrm{NH}_{4} \mathrm{SO}_{4}$ precipitation & 26 & 223.1936 & 1.06 \\
\hline 3 & $40 \% \mathrm{NH}_{4} \mathrm{SO}_{4}$ precipitation & 33 & 1004.3712 & 4.77 \\
\hline 4 & $60 \% \mathrm{NH}_{4} \mathrm{SO}_{4}$ precipitation & 30 & 669.580 & 3.18 \\
\hline 5 & $80 \% \mathrm{NH}_{4} \mathrm{SO}_{4}$ precipitation & 28 & 446.3872 & 2.12 \\
\hline 6 & $100 \% \mathrm{NH}_{4} \mathrm{SO}_{4}$ precipitation & 27 & 334.7904 & 1.59 \\
\hline 7 & Dialyzed STP & 37 & 1450.7584 & 6.89 \\
\hline
\end{tabular}

GCZ- Gelatin clearing zone 


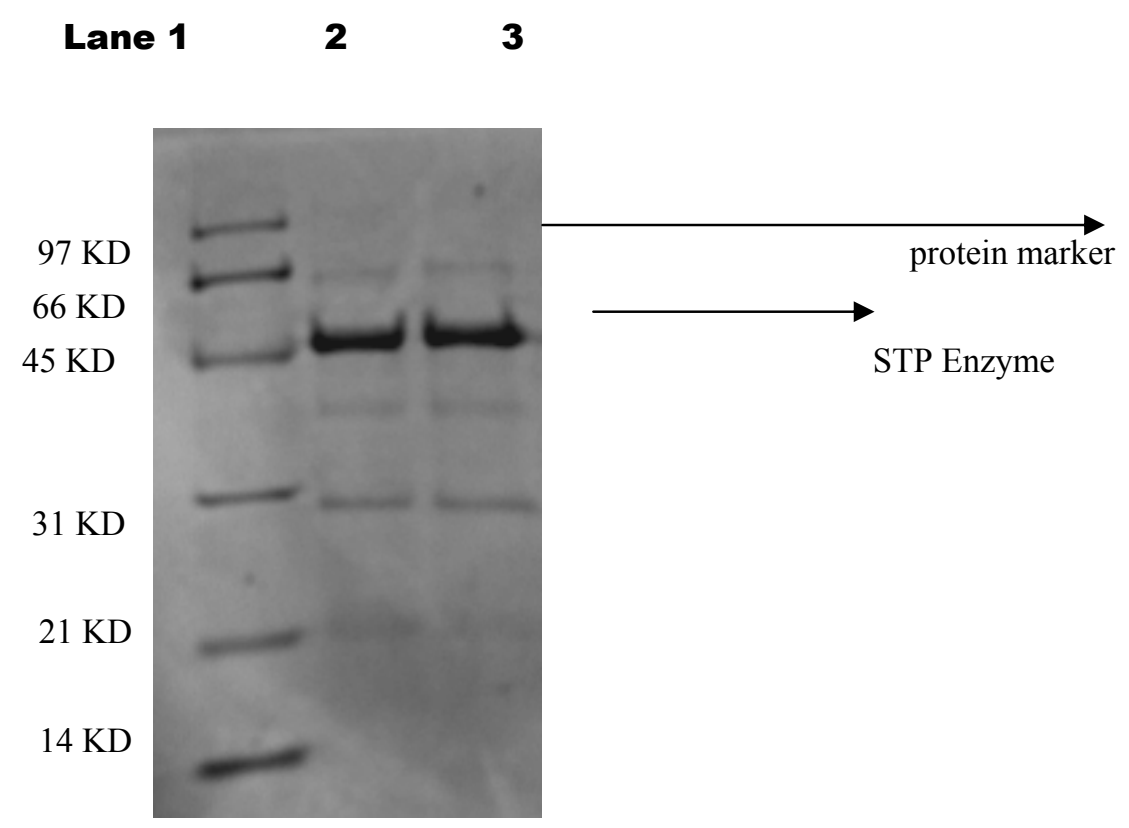

Plate 1.0 SDS-PAGE analysis of serratiopeptidase (STP) enzyme 